\title{
A Unique Pattern of Coagulation Abnormalities in Carbohydrate-Deficient Glycoprotein Syndrome
}

\author{
CHRIS VAN GEET AND JAAK JAEKEN \\ Department of Pediatrics [C.V.G., J.J.] and Centre for Thrombosis and Vascular Research [C.V.G.], University of \\ Leuven, Leuven, Belgium
}

\begin{abstract}
The carbohydrate-deficient glycoprotein syndromes are a recently individualized group of genetic multisystemic disorders. A predominant feature is a severe involvement of the central and peripheral nervous system resulting in psychomotor retardation, seizures, ataxia, and, mostly after infancy, stroke-like episodes. The hallmark biochemical feature is a carbohydrate deficiency in a large number of serum glycoproteins. Because coagulation factors and inhibitors are also glycoproteins, we performed a systematic study of these factors and inhibitors in nine patients with carbohydrate-deficient glycoprotein syndrome. All showed a decreased activity of factor XI and of the coagulation inhibitors antithrombin III and protein $C$. In five of seven patients more than $1 \mathrm{y}$ old, there was also a (less pronounced) decrease of protein $\mathrm{S}$ and of heparin cofactor II. This combined coagulation inhibitor deficiency could explain the stroke-like episodes occurring in these children. (Pediatr Res 33: 540-541, 1993)
\end{abstract}

Abbreviations

CDG syndrome, carbohydrate-deficient glycoprotein syndrome

The CDG syndromes are a newly recognized group of genetic multisystemic disorders. Over 100 infant and adult patients (1, 2 , and unpublished reports) are known. The clinical picture results predominantly from a severe involvement of the central and usually also the peripheral nervous system manifested as psychomotor retardation, seizures, and ataxia, as well as cerebral infarction and stroke-like episodes. Many other organs are variably affected, resulting in abnormal s.c. fat distribution ("peau d'orange"); retinitis pigmentosa; gastrointestinal, liver, and kidney disturbances; pericardial effusion, ascites; skeletal abnormalities; and hypogonadism. The hallmark biochemical feature is a deficiency of the three terminal sugars (sialic acid, galactose, and $\mathrm{N}$-acetylglucosamine) of secretory glycoproteins, causing abnormalities in a large number of serum glycoproteins such as transport proteins and enzymes $(1,3)$. Also, coagulation factor deficiencies have been reported sporadically $(1,4)$. We present here the results of a systematic study of blood coagulation factors and coagulation inhibitors in nine children with this syndrome.

\section{PATIENTS AND METHODS}

Nine patients (seven girls and two boys) were studied, ranging in age from 1 mo to $16 \mathrm{y}$ (Table 1 ). In all patients, the diagnosis

Received for rapid publication November 19, 1992; accepted January 6, 1993. Correspondence and reprint requests: Jaak Jaeken, M.D., Ph.D., Gasthuisbergkliniek, Kindergeneeskunde, Herestraat 49, B-3000 Leuven, Belgium. of CDG syndrome has been confirmed by isoelectric focusing of serum sialotransferrins showing a significantly decreased tetrasialo fraction and increased di- and asialo fractions (1). Patients 1, 2,4 , and 5 have been reported (summary in ref. 1 , pp. 68-71). It should be noted that patients 1 and 2 are monozygotic twin sisters, that patients 3 and 6 are brothers, and that the mothers on the paternal side of patients 5 and 7 are sisters. The parents of the patients were studied as well. The coagulation factor assays for factors II, V, VII, VIII, IX, X, XI, and XII were performed in a standard one-stage clotting assay using human deficient plasma as substrate. For factor XI, XI-deficient plasma was obtained from Organon Teknika (Turnhout, Belgium). The level of factor XIII transamidating activity was determined as described by Lorand et al. (6). Antithrombin III and protein C levels were quantified in a chromogenic substrate-based assay (Coatest Antithrombin III and Coatest Protein C, respectively, Chromogenix, Mölndal, Sweden). Free protein S-antigen was measured using a commercial ELISA method (Aserachrom Protein S, Diagnostica Stago, Asnières, France), and heparin cofactor II antigen was determined by Laurell-Electrophoresis with an antibody from Behringwerke (Marburg, Germany).

\section{RESULTS}

In all nine children, significantly decreased activities were found for coagulation factor XI and the coagulation inhibitors antithrombin III and protein C (Table 1). Most values were approximately $50 \%$ of the lower normal limit for age and, in the youngest child (patient 9 , age $1 \mathrm{mo}$ ), even lower. In five of seven patients more than $1 \mathrm{y}$ old, there was also a decrease, although less pronounced, of protein $S$ and of heparin cofactor II. In patients 3 and 6 (brothers), there was also a decreased activity of factor IX (57\% and 39\%, respectively; normal range $70-130)$.

The activities of the other coagulation factors and inhibitors studied were within normal limits (not shown). In the parents, coagulation factors and inhibitors were normal except for a decreased protein $\mathrm{C}$ activity in the father of patient $4(54 \%)$.

\section{DISCUSSION}

Coagulation factors and inhibitors are glycoproteins and, as far as known, are mostly of the N-linked complex type. Therefore, the multiple clotting factor deficiencies are most probably the consequence of the carbohydrate deficiency (partial deficiency of the terminal trisaccharide) that has been found in other secretory glycoproteins of children with this syndrome (1). Thus, the CDG syndromes seem to be the first instances in man of multiple coagulation abnormalities due to a primary carbohydrate defect. Several possibilities should be considered as to the mechanism by which this carbohydrate deficiency affects the activity of these coagulation factors: enhanced clearance by the liver, decreased stability, decreased secretory pathway, or loss of 
Table 1. Activities of factor XI and coagulation inhibitors (\%)

\begin{tabular}{|c|c|c|c|c|c|c|c|}
\hline $\begin{array}{c}\text { Patient } \\
\text { no. }\end{array}$ & Age & Sex & $\begin{array}{c}\text { Factor } \\
\mathrm{XI}\end{array}$ & $\begin{array}{l}\text { Anti- } \\
\text { thrombin } \\
\text { III }\end{array}$ & $\begin{array}{c}\text { Protein } \\
\mathrm{C}\end{array}$ & $\begin{array}{c}\text { Protein } \\
\mathrm{S} \\
\end{array}$ & $\begin{array}{c}\text { Heparin } \\
\text { cofactor } \\
\text { II } \\
\end{array}$ \\
\hline 1 & $16 y$ & $\mathrm{~F}$ & 40 & 46 & 38 & 50 & 47 \\
\hline 2 & $16 y$ & $\mathrm{~F}$ & 38 & 37 & 32 & 43 & 42 \\
\hline 3 & $10 \% / 12 \mathrm{y}$ & M & 32 & 36 & 36 & 70 & 55 \\
\hline 4 & $8 y$ & $\mathrm{~F}$ & 44 & 47 & 44 & 50 & 75 \\
\hline 5 & $7 y$ & $\mathrm{~F}$ & 29 & 46 & 32 & 59 & 35 \\
\hline 6 & $25 / 12$ y & M & 16 & 34 & 27 & 67 & 56 \\
\hline 7 & $15 / 12 y$ & $\mathrm{~F}$ & 19 & 24 & 21 & 74 & 62 \\
\hline \multicolumn{3}{|c|}{ Normal range at $>1 \mathrm{y}$} & $70-130$ & $70-130$ & $70-130$ & $70-130$ & $60-170$ \\
\hline \multicolumn{3}{|c|}{ Normal range at $3 \mathrm{mo}^{*}$} & $\begin{array}{c}15 \\
42-95\end{array}$ & $\begin{array}{c}29 \\
70-120\end{array}$ & $\begin{array}{c}17 \\
30-85\end{array}$ & $\begin{array}{c}59 \\
60-125\end{array}$ & $\begin{array}{c}36 \\
0-150\end{array}$ \\
\hline \multicolumn{3}{|c|}{ Normal range at $1 \mathrm{mo}^{*}$} & $\begin{array}{c}5 \\
26-84 \\
\end{array}$ & $\begin{array}{c}12 \\
50-110\end{array}$ & $\begin{array}{c}5 \\
20-65\end{array}$ & $\begin{array}{c}88 \\
37-95\end{array}$ & $\begin{array}{c}13 \\
7-90\end{array}$ \\
\hline
\end{tabular}

*From Ref. 5.

a direct effect of these carbohydrates on factor activities (7). An intriguing question is why these factors alone, and not the others, are affected. However, this should be not so surprising, as it is well known that the function of the carbohydrate portion can be different in different glycoproteins. The activity of protein $\mathrm{C}$ seems to be particularly sensitive to the carbohydrate deficiency, as it is in general more decreased than that of the other three coagulation inhibitors. Moreover, it is also decreased in the father of patient 4. This could be a coincidence, but it should be noted that some of these fathers (including the father of patient 4) have a partial (and only biochemical) expression of the disease as evidenced by a decreased serum thyroxine-binding globulin and apo B (3). In any case, the normal activity of the other factors excludes hepatocellular disease and vitamin $\mathrm{K}$ deficiency as causes of the defect.

What are the consequences of this well-defined, unique pattern of coagulation disorder? There is general agreement that factor $\mathrm{XI}$ deficiency in the order of magnitude observed here does not result in a hemorrhagic diathesis (8). On the other hand, each of the coagulation inhibitor deficiencies is a well-known cause of (mainly venous) cerebrovascular and other thromboses, particularly protein $\mathrm{C}$ deficiency. The combined coagulation inhibitor deficiency could make these patients especially prone to thromboembolic events, as was demonstrated in a family with an inherited triple deficiency of coagulation inhibitors (9). This could at least in part explain the stroke-like episodes and cerebral infarction found in a number of the patients with the CDG syndrome (1). The question arises whether this broad anticoagulation defect could be responsible for other features of this syndrome in the light of the recent finding that thrombin appears also in the brain and can induce neurite retraction in very low concentrations (10). This underscores the importance of thrombin inhibitors in the brain. A brain glycoprotein has recently been identified that binds to and inhibits thrombin and other proteases (protease nexin-1) (11). It is important to know whether this glycoprotein is also affected in CDG syndrome, because an imbalance in the activities of thrombin and protease nexin-1 might lead to loss of neuronal connections or to nerve cell damage.

Finally, our findings could have practical implications; the usefulness of anticoagulation treatment should be evaluated in these patients.

Acknowledgment. The authors thank Prof. J. Vermylen for critically reading the manuscript.

\section{REFERENCES}

1. Jaeken J, Stibler H, Hagberg B 1991 The carbohydrate-deficient glycoprotein syndrome: a new inherited multisystemic disease with severe nervous system involvement. Acta Paediatr Scand [Suppl] 375:1-71

2. Ohno K, Yuasa I, Akaboshi S, Itoh M, Yoshida K, Ehara H, Ochiai Y, Takeshita K 1992 The carbohydrate-deficient glycoprotein syndrome in three Japanese children. Brain Dev 14:30-35

3. Jaeken J, Eggermont E, Stibler H 1987 An apparent homozygous X-linked disorder with carbohydrate-deficient serum glycoproteins. Lancet 2:1398

4. Jaeken J, Stibler H 1989 A newly recognized inherited neurological disease with carbohydrate-deficient secretory glycoproteins. In: Wetterberg L (ed) Genetics of Neuropsychiatric Diseases. Wenner-Gren International Symposium Series, Vol 51. Macmillan Press, London, pp 69-80

5. Andrew M, Paes B, Milner R, Johnston M, Mitchell L, Tollefsen DM, Powers P 1987 Development of the human coagulation system in the full-term infant. Blood 70:165-172

6. Lorand L, Campbell-Wilkes LK, Coopertein L 1972 A filter paper assay for transamidating enzymes using radioactive substrate. Anal Biochem 50:623631

7. Rademacher TW, Parekh RB, Dwek RA 1988 Glycobiology. Annu Rev Biochem 57:785-838

8. Walsh PN 1992 Factor XI: a renaissance. Semin Hematol 29:189-201

9. Jobin F, Vu L, Lessard M 1991 Two cases of inherited triple deficiency in a large kindred with thrombotic diathesis and deficiencies of antithrombin III, heparin cofactor II, protein C and protein S. Thromb Haemostasis 66:295299

10. Marx J 1992 A new link in the brain's defences. Science 256:1278-1280

11. Gloor S, Odink K, Guenther J, Hanspeter N, Monard D 1986 A glia-derived neurite promoting factor with protease inhibitory activity belongs to the protease nexins. Cell 47:687-693 